\title{
Study of Fine Arts Education in Modern Museum
}

\author{
Jun Zhu \\ Huanggang Normal University \\ Huanggang, China
}

\author{
Shaozong $\mathrm{Hu}$ \\ Huanggang Normal University \\ Huanggang, China
}

\begin{abstract}
It is an effective way for the development of curriculum resources of fine arts education in schools by making full use of exhibit resources in museum and excavating their educational value. This paper, based on the analysis of Compulsory Education Fine Arts Curriculum Standard and Compulsory Education Art Curriculum Standard promulgated by the Ministry of Education in 2011, sorts up the concept of modern and contemporary museum management and the background of functional transformation, discusses the significance and methods of carrying out fine arts education using public cultural resources of museum.
\end{abstract}

Keywords-museum; new curriculum standard; fine arts education; humanistic quality

\section{INTRODUCTION}

The art of creation is an important part of human civilization and one of the spiritual activities of mankind. In the history of human culture, it penetrates into all aspects of social life. As an artistic form in the broad sense, it also has profound historical and cultural significance, and plays a role in the construction of social history and the creation of culture. Based on the analysis of Compulsory Education Fine Arts Curriculum Standard and Art Curriculum Standard promulgated by the Ministry of Education in 2011, this paper sorts up the concept of modern and contemporary museum management and the background of museum function transformation, discusses the significance and methods of carrying fine arts education using public cultural resources in the museum.

\section{CUltivating The HuMANisTiC SPIRIT: APPRECIATION AND COMMENT IN THE NEW CURRICULUM STANDARD OF FINE ARTS}

In 2011, the Ministry of Education announced the Compulsory Education Fine Arts Curriculum Standard, Compulsory Education Art Curriculum Standard. The two curriculum standards are interlinked and complement each other in terms of their contents, and put forward new requirements for national quality against contemporary society development, enabling the communication methods of learning images, the consciousness forming visual culture and the construction of creativity facing the 21 st century to be the basic orientation of contemporary basic fine arts curriculum. Fine arts carry and express human ideas, emotional attitudes and aesthetic taste, as well as enrich human spiritual and material worlds with visual images. Today's fine arts curriculum is characterized by the perception, understanding and creation of the visual image, and it is the main way for the school to conduct aesthetic education. The visual image here is a relatively broad human culture creation, which includes all the visual art forms in the general sense. Therefore, the Curriculum Standard clearly stipulates that the fine arts curriculum should highlight the visual, practical, humane as well as pleasure features. Among them, the requirements of humanities refers to that students shall learn to appreciate and respect the fine art works of different times and different cultures, pay attention to the fine arts phenomenon in the life, and cultivate humanistic spirit. Teaching requirements of the Appreciation - Commentary in the Curriculum Standards are as follows: pay attention to students' active participation, strive to stimulate students' subject consciousness, and guide students to grasp basic fine arts appreciation methods using diversified teaching forms, learn to collect relevant information through multiple channels such as art museum, museum, network, books and magazines, and constantly improve the students' ability of appreciation and commentary; guide the students to pay attention to the relationship between fine arts and society, to understand fine arts works in cultural context, to understand the creation of human material culture, and improve the humanistic quality. In the presentation of Curriculum Standard in various modules, "Modeling · Performance, Design · Application, and Exploration - Integration" emphasize the verbal meaning of the verb, that is to say, the teaching and learning evaluation in these areas is conducted based on practice process. "Appreciation - Commentary" is also to emphasize students to face art works, contact cultural circumstances and carry out experience, expression and judgment of all kinds of artistic value including aesthetic value.

The overall goal of art curriculum is to promote the comprehensive development of students' artistic ability and humanistic accomplishment. Therefore, when determining natures of art curriculum, the opinion in Compulsory Education Fine Arts Curriculum Standard is that art is humane, comprehensive, creative, pleasant and classic. In the elaboration of these characteristics, it gives priority to humanities, and believes that art curriculum is the course combining humanity and skills perfectly, which guides students to learn about civilization history of Chinese nation and various nations in the world through a vivid artistic image, feel the relation between art and human life, emotion, culture, science and technology, as well as experience of human's pursuit of truth and goodness. Art courses not only enable students to obtain the ability of appreciation and expression, but also get the noble sentiment, thus to have a richer humanistic care and more noble pursuit of value.

There is no doubt that it is a very effective way to guide students enter into the museum, in addition to the content as set out in textbooks, in terms of excavating the contents of art 
appreciation course and understanding the excellent cultural creation of the Chinese and foreign peoples. It should be said that this is not only the demand for international museum industry to change business philosophy, to achieve the social education function of museum, but also the field pursued by Chinese and foreign art education assiduously in recent years.

\section{COLLECTION OF HISTORY AND CULTURE: EDUCATIONAL FUNCTION OF MUSEUM}

The word "museum" is derived from the Greek language, which means the place for worshiping muse and conducting research. In Roman times, it was a place for philosophical discussion. Therefore, the museum was originally an integration of research institution, book-collection institution and academy. And its own collection makes it a complex of image, historical events and aesthetic creation. Modern museums integrate fine arts, practical art, archeology, anthropology, history, and science. It is, above all, the "Temple of Memory" of mankind, which collects, retains, displays and studies the typical material in kind that represents the creation of human culture, preserving our memories of the past and reproducing the social and historical values and natural values that have disappeared or are disappearing. ${ }^{1}$ According to China's current museum system, museums can be divided into two types:

The first: Museum of Fine Arts. Its main function is to collect, display, study those known as the art works, such as painting, sculpture, and practical art. In recent years, a variety of new multimedia art appear in the exhibition hall of major museums. Such museum of fine arts in China is directly called art museum, with the representatives including National Art Museum of China, Shanghai Museum of Art and so on. The artworks representing the highest national level are stored in various large-scale art museums. At the same time, some important art exhibitions are organized from time to time. They are engaged in the studies in art and culture, art and society centered on artistic creation research.

The second: museum in general sense. Its main feature is the collection, display and study of the material evidence left by the history, such as the National Museum of China, the Palace Museum and so on. According to the collection origin and subject category of culture, these museums can be classified into museum of ancient ruins, history museums, science museums and theme museums. Since the 1950s, the museums established countrywide at various provincial and municipal levels are the historical museums with local history as a clue. With the growth of archeology and constant excavation of archaeological sites in new China, a number of museums are established. Those museums established directly on the archaeological site for the effective protection of cultural relics and the reconstruction of historical and cultural scenes are known as museum of ancient ruins, such as the Terracotta Warriors and Horses Museum, Sichuan Guanghan Sanxingdui Museum and others. There are some theme museums established against special historical and cultural heritage, such as the Navigation Museum in Quanzhou, Fujian, Great Wall Museum in Jiayugua, Gansu. Science Museum is a museum collecting exhibits of specific discipline in accordance with modern disciplines, such as geological museums, marine museums, science museums and so on. Since 2006, in order to arrange number of visitors reasonably and protect the cultural relics, the state set regulations that museums are free to the public except museums of ruins is chargeable. This cultural measure has been widely supported by all sectors of society, reflecting the conversion of Chinese traditional museum with carrying out research as its mission to the modern museum combining research and education.

A few years ago, as for the nature and function of museum, Chinese Ministry of Culture has proposed a triple nature and two tasks, pointing out that the museum is a scientific research institution, a public educational institution, a physical evidence collection and protection institution. Two tasks refer to research and social services. Among the museums at home and abroad, there is a great change in the operation principle of museums. American museums believe that as the public cultural institutions, museums should actively participate in society. The community centralization of museums is a reform in museum emerging in this century. The American scholar Alexander put forward the viewpoint of "museum social centralization", believing that the museum become the social and cultural center because museum is the combination of historical value, research value and educational value. Its purpose is to build a museum into a community cultural center integrating various forms of artistic expression. For decades, the impact of this change has expanded year by year. The most important point is that modern museums adopt the popular and colorful forms of communication and education, adapting to the multicultural needs and aesthetic orientation of modern people, thus to obtain the public recognition and participation in community, making the museum vibrant, full of vitality, especially the European and American museums show a colorful new look in the course of community centralization. ${ }^{2}$

Dong Qi, Deputy Director of the National Museum of China holds the opinion that education is one of the main social functions of museum. The development of the times has led to the renewal of museum's educational concept and the innovation of educational activities. More and more knowledge is transmitted to the audiences by museum education with increasingly high content of new technology. The dissemination of knowledge is no longer one-way transmission to the educated by education, but two-way communication and interactive impact. The purpose of museum education is no longer to "teach", but to help the audience to "learn." Museum achieves its educational purpose by providing service for audiences' self-learning. From various types of social services developed by all kinds of museums we can see that, the museum's educational methods can be divided into the following categories: serve for scientific research, serve for the majority of audiences to improve cultural literacy, serve for students' out-of-school education, and serve for tourism and cultural leisure services. Museum is an integral part of the cause of human culture; its fundamental task is to serve the reality based on history; it is ultimately to contact with the society. Transmit information to the society and realize connection to the society through exhibitions, exhibitions, communication and other means using its own collection of resources. This process is actually the practice of museum's educational function. And the fulfillment of 
educational function for the society has become an important symbol of modernization of the museum. ${ }^{3}$

Museum education in narrow sense generally refers to the educational activities planned and designed, organized and implemented by education department of the museum, which is responsible for cooperating with other departments of the museum or relevant groups, to attract audiences based on museum collections and academic resources as well as audience market analysis; the activities must have specific education objects, themes, objectives, content and time, venue, equipment. During the activity, the educators should conduct face-to-face contact, communication and interaction with the audiences, to ensure regular and systematic educational activities to be held; after the end of each event, the museum educators must summarize the experience of gains and losses in time, and make feedback to other departments of the museum, museum counterparts and audiences. ${ }^{4}$ Museum education in a broad sense means that activities conducted in museum, as long as they contain the functions and meanings of education, can be regarded as museum education, including collections, research, exhibitions and so on. As what Jasmine Harrison, a famous museum scientist says: "Everything done in a museum shall be of educational significance, even if it is not intended." However, the design level of each exhibition, the quality of design concept, the friendly and sincere attitude of the staff, the equipment in the hall, the design of the equipment, the printed style, and the contents of publications are all a kind of potential impact inspiring the visitors, and are part of the education services project." ${ }^{5}$ In addition, some museum scientists believe that the real museum education is from the learner's own experience, especially the experience of learners to take the initiative to participate in the activity. As a result, "museum education" only shows the meaning of passive acceptance by audiences without reflecting the audience to visit museum with self-guidance according to individual interest, and experience the educational activities provided by education department of museum. Therefore, the term "museum learning" is more appropriate than "museum education". Taiwan scholar Huang Shufang summarizes the museum education methods into three categories in his book "Modern Museum Education: Concepts and Practice": first is the basic educational activities in the museum, the second is to coach the school education activities, and the third is the education activity of community service. ${ }^{6}$

Therefore, the museum education is not only the dissemination of knowledge, more importantly, it carries forward the scientific spirit and humanistic spirit, cultivates sentiments, and improves the overall quality. To develop the cause of museum, the museum's own vitality shall be depended on via continuous theoretical innovation, adjust the operation mechanism and management mechanism to stimulate creativity and imagination, to make cultural market boom by joint efforts from the society and promote the development of cultural undertakings.

\section{AUTONOMY AND OPENING: THE FORM OF ART EDUCATION IN MUSEUM}

The combination of the educational function of the museum and the school education can be multidisciplinary, and each discipline can find the connection point of this subject specialty here, thus to realize the pursuit of cultural history and discipline development with exhibits as the center. Compared with school education, teaching activities here are both changes in teaching space, but also the expansion of teaching content, at the same time they are also the conversion of teaching methods and the teacher-student relationship. Teaching and learning in the museum is an autonomous and open process.

Human art activities are carried by the visual image and expression of human thought, emotional attitudes and aesthetic taste, rich people's spiritual and material world. In the whole history of mankind, especially in the early period of human social history, vision and image have always been the main intellectual means for us to understand the world, express thoughts and emotions and record past events. The primary feature of this cultural activity is the vision, which is the essential characteristic of its disciplinary attribution. The material carrier in the museum not only embodies its cultural significance, but also presents its visual aesthetic significance, because the form of material carrier is the external manifestation of cultural connotation. Starting from the visual teaching and research is the discipline attributes of fine arts, of course, is an important way of fine arts teaching.

The education of modern museum presents the following characteristics and development trends:

First, the museum's display and educational activities are increasingly active and diversified, creating a lively learning atmosphere with high participation, and give the audience a pleasant learning experience and a broader imaginary space through sensory contact.

Second, the audience can choose the educational services provided by museum according to their own preferences, ability and autonomy to form the self-guided and exploratory learning method.

Third, through the scene reproduction, site restoration, inkind landscaping, the museum improves the audiences' involvement in visiting, thus to obtain the immersive learning experience.

Fourthly, the development of computer technology and network makes the dissemination of museum education gradually get rid of the limitations of time and space, and penetrates into various places in the world. Therefore, the museum is not only a treasury of cultural relics and artworks, but also extends to become the educational role of learning center, providing the audience more learning opportunities and cultural resources. ${ }^{7}$

The educational and teaching activities carried out in the museum can be very flexible with varied activity level and diversified themes, which can be designed against different exhibits. But these problems can be divided into three levels: 


\section{A. Observation and Description}

When it comes to the nature of curriculum, Compulsory Education Art Curriculum Standard believes that the curriculum of fine arts education is characterized by the perception, understanding and creation of visual image. Emphasize the experience accumulation of vision, feeling and other sensory during the study, develop the perceptual ability, and gradually improve the ability to understand and comment, learn to understand fine arts in the cultural context. The first level of learning in the museum shall be observation and description against the teaching requirements and teaching objectives of this course. Observation is the beginning of learning and the first step of form appreciation. It takes a single exhibit as a unit.

The individual information of museum collections include: material, size, color and texture, exhibit name, function, processing technology, national attribute, display mode, space environment and so on. These are the observation contents of the exhibits. Description is the language expression of observation order and exhibit selection based on observation, and the logical presentation of observation object. This level of activity can be done independently by the students, or be conducted in a group. Its process is characterized by autonomy, openness and complementarity.

\section{B. Construction and Expression}

Any exhibit of museum is a small display unit formed in accordance with particular logical relationship, and the small units with some kind of association constitute a relatively independent theme. The main body and unit render the museum the main order, which not only provides the convenience for the audience to visit, but also manifests the exhibition organizer's affirmation of the value of exhibits. The unit and theme of collections of museum are the historical and cultural construction based on historical background and time cues. This level of teaching requires teachers to actively create good museum experience, give play to the appeal of cultural relics and collections of museums to students. During the activity, teachers actively learn about the students' interests and concerns, play the role of cooperative learners, change the attitude of preachers, and emphasize the museum learning atmosphere of free choice. On this basis, enable students to make further description that is in line with historical and cultural scenarios.

The above two levels of teaching activities are carried out generally from the following links: the development of teaching objectives - the preparation of teaching environment hint of background unit content of the exhibits - display visiting - to find the associated content - reading and construction the cultural scene of exhibits - activity review and experience sharing and other steps. The whole process of education can be completed inside and outside the school, as well as inside and outside the museum several times.

\section{Judgement and Analysis}

The value of museum collections is a multidimensional structure. After understanding the cultural background of the object, it is necessary to make the comment and judgment that are in line with their emotional needs and aesthetic perception. The activity at this level is based on the second level, and it is the inevitable result of the previous level. The reflections on and evaluation recommendations of art and culture in Compulsory Education Art Curriculum Standard suggest that students should talk about the meaning of symbols in artworks as well as think about and discuss the reason of varied artistic expression modes of different nationalities in different regions. Establish a comprehensive understanding of museum cultural collections and sum up how these features are reflected in the exhibits through comparative analysis of different cultural situations, different historical backgrounds, different nationalities, different regions exhibits, and different means of expression, so as to improve the humanistic quality.

The learning process of above three levels is not absolute separation. In the specific teaching activities, the three are characterized by interactive development. Each individual learner can proceed flexibly based on their own interests, knowledge reserves, time and space, obtaining artistic aesthetic enjoyment, getting rich historical and cultural knowledge.

\section{CONCLUSION}

The audiences walk into the museum to watch exhibits and appreciate the exquisite shapes left by the ancients. By doing so, they not only linger on their intriguing form, exquisite craftsmanship, but also pursue the historical clues hidden behind those items, curious about historical and cultural scene that has already passed away. Those collections lying quietly in museum also reflects the tenderness of history, revealing scenes of fresh historical picture for us, giving us a multi-angle humanity history information and rich inspiration. It is an effective way for the curriculum resources development in the fine arts education of the contemporary school by making full use of the exhibit resources of the museum and excavating their educational value.

\section{REFERENCES}

[1] In 1974, experts made further definition of the nature of museum: a non-profit, permanent institution open to the public, serving society and its development, collecting, preserving, researching, communicating and demonstrating the material evidence of human beings and their environment for research, education and appreciation purposes. Cao Yiqiang: Introduction to Fine Arts Museology, China Academy of Art Publishing House, 2008, p2-4.

[2] Zeng Guangqing: Community Centralization---Reform of Museum Education Mode, Cultural Relics of Central China, 1999, No.:4.

[3] Chen Ping. Reflections on School-oriented Educational Function Implementation by Museum, Museum Research, 2007, No.: 2.

[4] Chen Weiping. Constructivism and Museum Education, Chinese Museum, 2003, No.:2.

[5] Cheng Jingsheng. On Museum Social Education and Children Education, Communication of Chinese Museum, 1997, No.: 12.

[6] Huang Shufang. Modern Museum Education: Philosophy and Practice, Taipei: Taiwan Provincial Museum, 1997, p43.

[7] Cao Mo. Analysis of the Implementation Process of Children's Educational Activities in Museum---Taking Museums in Shanghai as an Example, Department of Cultural Relics and Museums, Fudan University, Master Thesis 2010. 